\title{
Selective Action of Orexin (Hypocretin) on Nonspecific Thalamocortical Projection Neurons
}

\author{
Laurence Bayer, ${ }^{1 *}$ Emmanuel Eggermann, ${ }^{\text {* }}$ Benoît Saint-Mleux, ${ }^{1}$ Danièle Machard, ${ }^{1}$ Barbara E. Jones, ${ }^{2}$ \\ Michel Mühlethaler, ${ }^{1}$ and Mauro Serafin ${ }^{1}$ \\ 1Département de Physiologie, Centre Médical Universitaire, 1211 Geneva 4, Switzerland, and 2Department of Neurology \\ and Neurosurgery, McGill University, Montreal Neurological Institute, Montreal, Quebec, Canada H3A 2B4
}

\begin{abstract}
As is evident from the pathological consequences of its absence in narcolepsy, orexin (hypocretin) appears to be critical for the maintenance of wakefulness. Via diffuse projections through the brain, orexin-containing neurons in the hypothalamus may act on a number of wake-promoting systems. Among these are the intralaminar and midline thalamic nuclei, which project in turn in a widespread manner to the cerebral cortex within the nonspecific thalamocortical projection system. Testing the effect of orexin in rat brain slices, in two nuclei of this system, centromedial (CM) nuclei and rhomboid nuclei, we found that it depolarized and excited all neurons tested through a direct postsynaptic action. An additional analysis of this effect in $\mathrm{CM}$ neurons indicates that it results from the decrease of a potassium conductance. By a detailed comparison of the effects of orexin A and B, we established that orexin B was more
\end{abstract}

Recent experimental evidence has shown that orexin (hypocretin) peptides are implicated in maintaining the state of wakefulness. Indeed, alterations in their receptors (Lin et al., 1999) and their precursor protein (Chemelli et al., 1999) and lesion of the neurons that secrete the orexins (Nishino et al., 2000; Peyron et al., 2000; Thannickal et al., 2000; Hara et al., 2001) are all associated with a decrease in wakefulness and the pathological appearance of sudden sleep onset or narcolepsy (for review, see Siegel, 1999; Kilduff and Peyron, 2000; Sutcliffe and de Lecea, 2000; Hungs and Mignot, 2001; Willie et al., 2001).

The orexins (orexin A and B or hypocretins 1 and 2) are two neuropeptides synthesized by a group of neurons in the lateral hypothalamus and perifornical area (de Lecea et al., 1998; Sakurai et al., 1998), which give rise to widespread projections through the brain and spinal cord (Peyron et al., 1998; van den Pol, 1999). These peptides have corresponding receptors (Sakurai et al., 1998), orexin-1 [OX ; $_{1}$ also known as hypocretin 1 (Hcrtr1)] and orexin-2 $\left(\mathrm{OX}_{2}\right.$; also known as Hcrtr2), differentially expressed throughout the CNS (Lu et al., 2000; Marcus et al., 2001). Both orexin fibers and receptors are densely distributed in brain regions known to be important for the

\footnotetext{
Received April 12, 2002; revised June 10, 2002; accepted June 11, 2002.

This study was supported by grants from the Swiss Fonds National; the Novartis, OTT, de Reuter, and Schmidheiny Foundations to M.M. and M.S.; the Canadian Medical Research Council to B.E.J.; and a Roche fellowship to L.B.

*L.B. and E.E. contributed equally to this work.

Correspondence should be addressed to Dr. Mauro Serafin, Département de Physiologie, Centre Médical Universitaire, 1 Rue Michel-Servet, 1211 Geneva 4, Switzerland. E-mail: mauro.serafin@medecine.unige.ch.

Copyright (C) 2002 Society for Neuroscience $0270-6474 / 02 / 227835-05 \$ 15.00 / 0$
}

potent than orexin $A$, indicating the probable mediation by orexin type 2 receptors. In contrast to its effect on the nonspecific thalamocortical projection neurons, orexin had no effect on the specific sensory relay neurons of the somatic, ventral posterolateral, and visual dorsal lateral geniculate nuclei. Orexin differs in this regard from norepinephrine and acetylcholine, to which neurons in the specific and nonspecific systems are sensitive. Orexin may thus act in the thalamus to promote wakefulness by exciting neurons of the nonspecific thalamocortical projection system, which, through widespread projections to the cerebral cortex, stimulate and maintain cortical activation.

Key words: arousal; intralaminar nuclei; midline nuclei; rat; sleep; wakefulness

promotion and maintenance of wakefulness (for review, see Jones, 2000). These target areas include the thalamus, the afferent gateway to the cerebral cortex, through which transmission is modulated across the sleep-waking cycle (Steriade and Llinás, 1988; Steriade et al., 1997). Neurotransmitters from the brainstem activating systems, including notably noradrenaline (NA) and acetylcholine (ACh), act on thalamocortical neurons to provoke a depolarization and resulting change in firing pattern from bursting to tonic, and thus from slow to fast, activity subtending both sensory transmission and cortical activation during arousal (for review, see Steriade and Llinás, 1988; McCormick and Bal, 1997; Steriade et al., 1997; Jones, 2000). In contrast to noradrenergic and cholinergic fibers, orexinergic fibers appear to avoid the sensory relay nuclei of the thalamus and focus their innervation on the intralaminar and midline nuclei (Peyron et al., 1998). These nuclei also receive input from the brainstem reticular formation and project in a widespread manner to the cerebral cortex, forming a nonspecific thalamocortical projection system that is capable of stimulating and maintaining widespread cortical activation (Steriade and Llinás, 1988; Steriade et al., 1997). To examine the action and potential role of orexin in the thalamus, we first examined the effect of the orexin $\mathrm{A}$ and $\mathrm{B}$ peptides on the centromedial (CM) nucleus and rhomboid ( $\mathrm{Rh}$ ) nucleus of the nonspecific thalamocortical projection system and second, tested their effect on the somatic, ventral posterolateral (VPL), and visual dorsal lateral geniculate (DLG) sensory relay thalamic nuclei within rat brain slices. 


\section{MATERIALS AND METHODS}

Electrophysiological recordings. Brain slices were obtained from young rats (15-20 d of age) reared at the animal facility of the Geneva Medical Center and treated according to the regulations of the Swiss Federal Veterinary Office. The optimal coronal slices (300 $\mu \mathrm{m}$ thick) for recording from CM, Rh, VPL, and DLG neurons were selected according to a rat brain atlas (Paxinos and Watson, 1997). Before use, the slices were incubated at room temperature in artificial CSF (ACSF), which contained (in mM): $130 \mathrm{NaCl}, 5 \mathrm{KCl}, 1.25 \mathrm{KH}_{2} \mathrm{PO}_{4}, 1.3 \mathrm{MgSO}_{4}, 20$ $\mathrm{NaHCO}_{3}, 10$ glucose, and $2.4 \mathrm{CaCl}_{2}$, bubbled with a mixture of $95 \% \mathrm{O}_{2}$ and $5 \% \mathrm{CO}_{2}$. Experiments in which $E_{\mathrm{K}}$ was changed were done with the following ACSF (in $\mathrm{mM}$ ): $130 \mathrm{NaCl}, 5$ or $12 \mathrm{KCl}, 1.3 \mathrm{MgCl}_{2}, 20$ $\mathrm{NaHCO}_{3}, 10$ glucose, and $2.4 \mathrm{CaCl}_{2}$. Individual slices were transferred to a thermoregulated $\left(32^{\circ} \mathrm{C}\right)$ chamber on a Zeiss (Oberkochen, Germany) Axioskop equipped with an infrared camera (Dodt and Zieglgansberger, 1994). Slices were kept immersed and continuously superfused at $3-5 \mathrm{ml} / \mathrm{min}$. Patch electrodes were pulled on a DMZ universal puller (Zeitz-Instrumente, Munich, Germany) from borosilicate glass capillaries (GC150F-10; Clark Instruments, Edenbridge, UK). The pipettes (5-10 M $\Omega$ ) contained the following solution (in $\mathrm{mM}$ ): $126 \mathrm{KMeSO}_{4}, 8$ phosphocreatine, $4 \mathrm{KCl}, 5 \mathrm{MgCl}_{2}$, $10 \mathrm{HEPES}, 3 \mathrm{Na}_{2} \mathrm{ATP}, 0.1 \mathrm{GTP}$, and 0.1 BAPTA, pH 7.4 (290-310 mOsm; estimated junction potential, - 9.5 $\mathrm{mV})$. Recordings were made in the whole-cell configuration using the Axopatch 200 B (Axon Instruments, Foster City, CA) in the currentclamp mode. Neurobiotin (0.2\%; Vector Laboratories, Burlingame, CA) was added to the intrapipette solution when needed. Orexin A and B (Bachem, Bubendorf, Switzerland) were tested by dissolving the peptides at the proper concentration in the perfusion solution. Synaptic blockade was realized by lowering calcium and increasing magnesium $(0.1 \mathrm{~mm}$ $\mathrm{Ca}^{2+}, 10 \mathrm{~mm} \mathrm{Mg}^{2+}$ ). To measure the orexin-induced changes in the input membrane resistance, short-lasting hyperpolarizing current pulses were applied repetitively. At the maximum of the depolarizing effect of the orexins, the membrane potential was clamped manually back to its resting value, thus allowing us to evaluate the change in membrane resistance.

Histology. After electrophysiological recordings, slices containing thalamic neurons were fixed in an ice-cold solution containing $3 \%$ paraformaldehyde. Neurobiotin-filled neurons were subsequently visualized using the avidin-biotinylated horseradish peroxidase complex reaction (Vectastain; ABC Elite kit; Vector Laboratories) with 3,3' diaminobenzidine (Sigma, St. Louis, MO) as a chromogen. In this condition, the limits of the thalamic nuclei could be determined visually under the microscope by differential background staining with respect to surrounding structures. Photomicrographs were realized with a digital microscope camera (Axiocam; Zeiss) and printed with Photoshop 6.0 (Adobe Systems, San Jose, CA).

Data analysis. Curve fitting was performed according to the following equation: $Y=Y_{\min }+\left(Y_{\max }-Y_{\min }\right) /\left[1+10^{([\log \text { EC50 }-\log (\text { orexins })] \times \text { Hill slope })}\right]$ with Prism 3.0 (Graph Pad software, San Diego, CA). Because orexin A and $\mathrm{B}$ were both ineffective between 0.1 and $4.0 \mathrm{~nm}$ and because their effects were not significantly different at $100 \mathrm{nM}, Y_{\min }$ and $Y_{\max }$ were fixed at 0 and $22.04 \mathrm{mV}$, respectively (mean value of the membrane depolarization induced by either orexin A or B at $100 \mathrm{~nm}$ ). Data (change in membrane resistance, orexin-induced depolarizations) were tested for significance with the Student's two-population paired $t$ test. All values are given as mean \pm SEM.

\section{RESULTS}

\section{CM thalamic neurons are depolarized and excited by the orexins}

Neurons, localized in the CM area under infrared videomicroscopy, were recorded in current clamp using the whole-cell mode. In the absence of stimulation, the CM neurons displayed no spontaneous activity. Membrane depolarization from rest elicited tonic firing, as evidenced in Figure $1 A$, whereas depolarization from a hyperpolarized level was characterized (Fig. $1 B$ ) by the presence of a potent low-threshold spike (LTS, asterisk) crowned by a burst of fast action potentials. As expected from previous studies (Deschênes et al., 1984; Jahnsen and Llinás, 1984), the LTS was calcium-dependent, because it always persisted in the presence of TTX at $1 \mu \mathrm{M}(n=13$ of 13$)$ but was eliminated by nickel at $200 \mu \mathrm{M}(n=3$ of 3$)$.

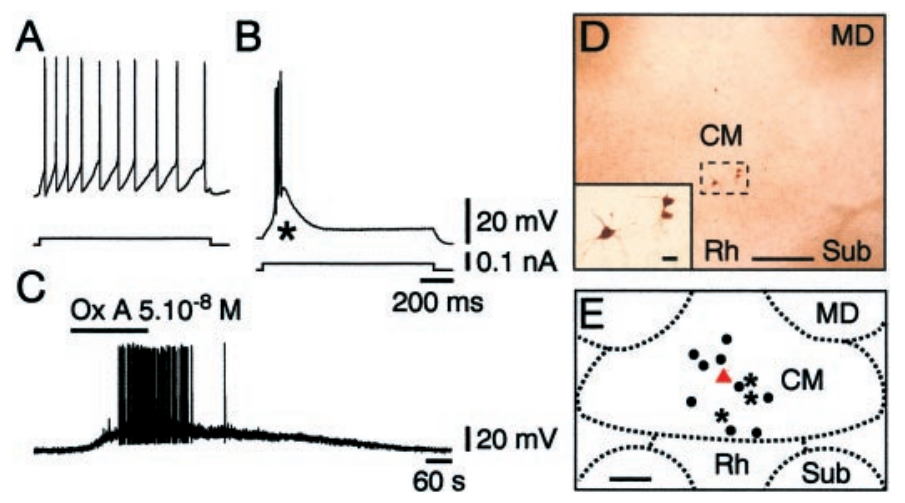

Figure 1. Localization of orexin (hypocretin)-responsive neurons in the $\mathrm{CM}$ intralaminar thalamic nucleus. $A, B$, Characterization of a $\mathrm{CM}$ neuron with its responses to a depolarizing current step delivered from rest $(A)$ or from a hyperpolarized level $(B)$, showing the typical strong LTS (asterisk). $C$, Depolarizing and excitatory action of orexin A $(O x A)$. $D$, Three CM neurons that have responded to orexins are shown (enlarged in inset) within a single slice. $E$, All neurobiotin-filled neurons ( $n=$ 13 , dots, asterisks, and triangle), including the one (red triangle) illustrated in Figure $2 D$ and the three (asterisks) shown in $D$, are within the limits of the CM neurons. Scale bars: $D, 250 \mu \mathrm{m}$; inset in $D, 25 \mu \mathrm{m} ; E, 500 \mu \mathrm{m} . M D$, Mediodorsal thalamic nucleus; $S u b$, submedius thalamic nucleus.

As illustrated in Figure $1 C$, all thalamic neurons $(n=49)$ in the region of the $\mathrm{CM}$ nucleus were potently depolarized and excited by the orexins (orexin A or B or both). Moreover, the orexininduced effect was found to be postsynaptic, because it persisted in conditions of synaptic blockade $\left(0.1 \mathrm{mM} \mathrm{Ca}^{2+}\right.$ and $10 \mathrm{~mm}$ $\mathrm{Mg}^{2+} ; n=3$ of 3$)$ and in the presence of TTX at $1 \mu \mathrm{M}(n=19$ of 19). Responsive neurons filled with neurobiotin, as illustrated in Figure $1 D$ for three of them, were all $(n=13$ of 13$)$ located within the confines of the CM nucleus (Fig. 1E).

\section{Excitation by orexins of CM neurons involves $\mathrm{OX}_{2}$ receptors}

In a number of experiments $(n=27)$, orexin A and B were tested on the same neurons to compare their respective potencies. When tested at the same concentration, orexin B usually elicited a stronger depolarization than orexin A (Fig. 2, compare $A$ and $B$ ). Because this difference indicates that the receptor involved could be of the $\mathrm{OX}_{2}$ type (Sakurai et al., 1998), we systematically compared orexin A- and orexin B-induced depolarizations over a broad range of concentrations (from 0.1 to $200 \mathrm{~nm}$ ). Although both peptides were always ineffective at concentrations of $<10$ $\mathrm{nM}$, orexin B depolarized the cells ( $n=6$ of 6 ) by $4.15 \pm 1.0 \mathrm{mV}$ $($ mean \pm SEM) at $10 \mathrm{~nm}$, whereas orexin A had no effect $(n=0$ of 6) at that concentration. Results were significantly different at higher concentrations, with depolarizations for orexin $\mathrm{A}$ and $\mathrm{B}$ of $2.27 \pm 0.28$ versus $10.66 \pm 0.75 \mathrm{mV}\left(t=14.808 ; p=5963 \times 10^{-6}\right.$; $n=7)$ at $20 \mathrm{nM}$ and $10.38 \pm 0.71$ versus $19.12 \pm 1.98 \mathrm{mV}(t=$ $3.3364 ; p=0.0206 ; n=6$ ) at $30 \mathrm{~nm}$. At $100 \mathrm{~nm}$, the effects of both peptides reached their maximum and became indistinguishable (with depolarizations for orexin $\mathrm{A}$ and $\mathrm{B}$ of $21.89 \pm 0.85$ versus $22.19 \pm 0.87 \mathrm{mV} ; t=1.4872 ; p=0.1591 ; n=15)$. When the entire database was pooled and plotted (Fig. $2 C$ ), $\mathrm{EC}_{50}$ values of $32.0 \mathrm{~nm}$ for orexin A and $18.3 \mathrm{~nm}$ for orexin $\mathrm{B}$ were found, confirming that orexin B was more potent than orexin A on CM neurons. As illustrated in the upper insets of Figure $2 D$, it is noteworthy that CM neurons, which were silent at rest and fired a rebound burst after current-pulse injections, adopted a tonic discharge in response to the orexins. 

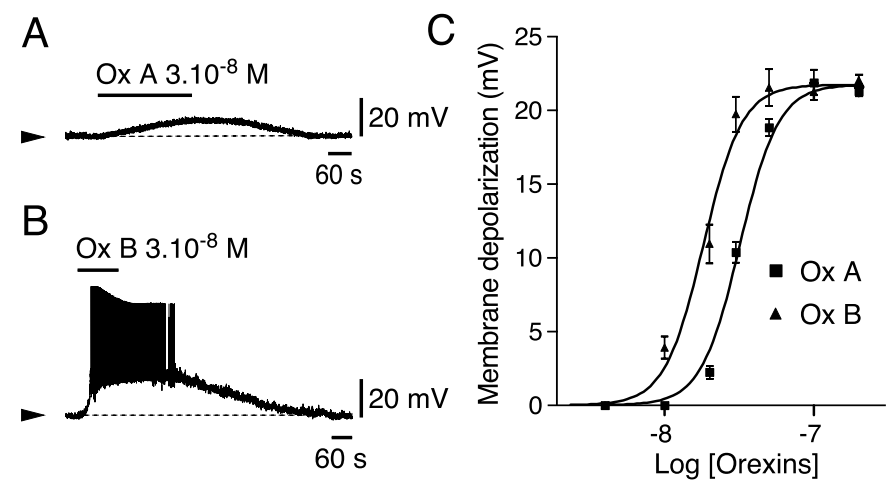

D

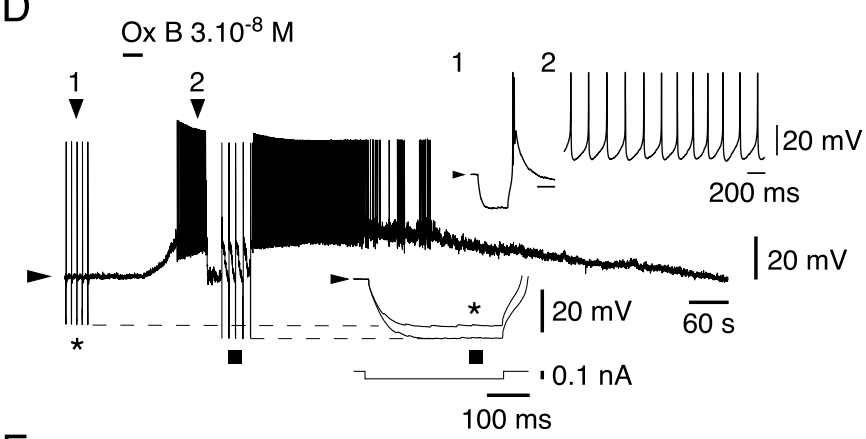

E

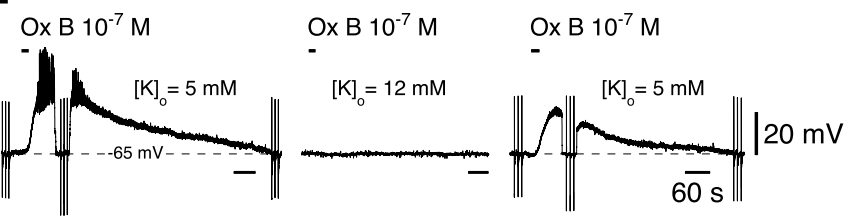

Figure 2. Effects of orexin (hypocretin) on CM neurons. $A, B$, Effects of orexin $\mathrm{A}(O x A)$ and orexin $\mathrm{B}(O x B)$ on the same $\mathrm{CM}$ neuron. $C$, Dose-response curves to Ox A and Ox B (for the two peptides at consecutive concentrations: $n=4$ and 4 at $4 \mathrm{~nm}, 7$ and 9 at $10 \mathrm{~nm}, 8$ and 10 at $20 \mathrm{~nm}, 6$ and 11 at $30 \mathrm{~nm}, 3$ and 6 at $50 \mathrm{~nm}, 15$ and 27 at $100 \mathrm{~nm}$, and 4 and 4 at $200 \mathrm{nM}$, respectively). $D$, Comparison of hyperpolarizing pulses before (asterisk) and during (square) the effect of orexin (see bottom inset enlargement of the pulses demonstrating the increase in membrane resistance in the presence of orexin). Top inset enlargements (corresponding to positions 1 and 2 of the original trace) illustrate the rebound burst after a hyperpolarizing pulse delivered from the resting level under control conditions (1) and the tonic firing during the effect of orexin (2). E, The depolarizing effects of orexin (left) are reversibly suppressed (right) when neurons are held at $E_{\mathrm{K}}$ (middle).

The orexin-induced depolarization was always accompanied by an increase in membrane input resistance (Fig. 2D) (mean increase $\pm \mathrm{SEM}=17.28 \pm 1.21 \%, n=17$, for orexin $\mathrm{B}$ and $16.02 \pm$ $0.44 \%, n=7$, for orexin A), an effect that did not differ significantly between the two peptides (paired $t$ test: $t=0.0137 ; p=$ $0.9896 ; n=6$ ) and could reflect the closure of a potassium conductance. To test this hypothesis, we compared (in the presence of $1 \mu \mathrm{M}$ TTX) the effects of orexin on neurons maintained at a membrane potential of $-65 \mathrm{mV}$ in two different conditions of external potassium concentration $\left([\mathrm{K}]_{\mathrm{o}}\right)$, resulting in two different equilibrium potentials for potassium $\left(E_{\mathrm{K}}\right)$. As shown in Figure $2 E$ (left), in the first condition $\left([\mathrm{K}]_{\mathrm{o}}=5 \mathrm{mM}\right.$; estimated $E_{\mathrm{K}}=-87.5$ $\mathrm{mV}$ ), orexin depolarized CM neurons powerfully, as shown previously. In contrast, when tested again in the second condition (Fig. $2 E$, middle $)\left([\mathrm{K}]_{\mathrm{o}}=12 \mathrm{~mm}\right.$; estimated $\left.E_{\mathrm{K}}=-64.5 \mathrm{mV}\right)$, application of orexin had no effect $(n=6$ of 6$)$. When returned to the original condition, the depolarizing effect of orexin was re-

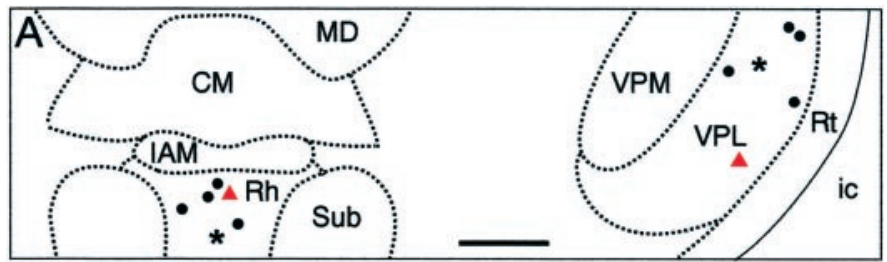

D

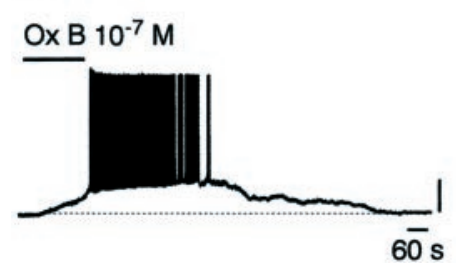

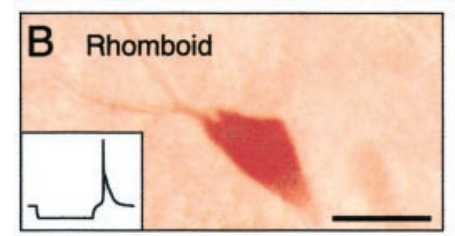

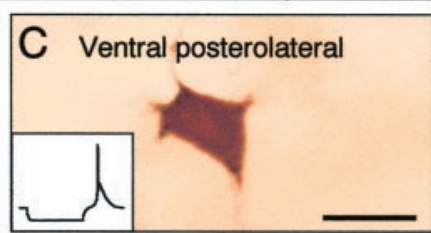

E

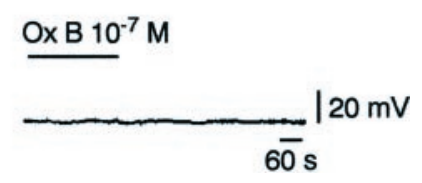

Figure 3. Actions of orexin (hypocretin) on Rh and VPL neurons. $A$, Localizations of the $\mathrm{Rh}$ and VPL nuclei with all injected cells (dots, asterisks, and triangles). IAM, Interanteromedial thalamic nucleus; $i c$, internal capsule; $M D$, mediodorsal thalamic nucleus; $S u b$, submedius thalamic nucleus; VPM, ventral posteromedial thalamic nucleus; $R t$, reticular thalamic nucleus. Red triangles correspond to the injected cells shown in $B$ and C. $B, C$, Neurobiotin-filled neurons in the $\mathrm{Rh}$ and VPL nuclei (insets showing characteristic responses to hyperpolarizing pulses). $D$, Depolarizing and excitatory effect of orexin in the Rh neurons. $E$, Absence of effect of orexin in the VPL. Scale bars: $A, 500 \mu \mathrm{m} ; B, C, 20 \mu \mathrm{m}$.

covered (Fig. 2E, right), although it was often slightly diminished in amplitude. Of final note, CM neurons were also depolarized and excited ( $n=2$ of 2) by either carbachol (a nondegradable cholinergic agonist) or NA applied at $10 \mu \mathrm{M}$ (data not shown).

\section{Orexins excite neurons of the Rh nucleus}

We subsequently turned to the action of the orexins on the midline Rh neurons. All of the neurons recorded in this nucleus were silent at rest and, when challenged by hyperpolarizing current pulses, displayed an LTS as in CM neurons. As shown in Figure $3 A, B$, the recorded cells were filled with neurobiotin and localized within the confines of the $\mathrm{Rh}$ area $(n=6)$. In response to orexins applied at concentrations between 50 and $100 \mathrm{~nm}$, all cells $(n=5$ of 5$)$ tested for responses to both peptides were depolarized and excited. An example of a response to orexin B is illustrated in Figure $3 D$. As in the CM neurons, the effects were postsynaptic, because they persisted in a low-calcium, highmagnesium solution ( $n=2$ of 2). Comparison of effects at $50 \mathrm{~nm}$ showed that orexin $\mathrm{B}$, with a depolarization of $18.38 \pm 1.40 \mathrm{mV}$, was significantly more potent than orexin $\mathrm{A}$, with a depolarization of $8.13 \pm 3.22 \mathrm{mV}(t=4.027 ; p=0.028 ; n=4)$, thus suggesting that $\mathrm{OX}_{2}$ receptors are again involved in the action of orexins. Finally, as in the $\mathrm{CM}$ neurons, Rh neurons were also depolarized and excited ( $n=2$ of 2$)$ by either carbachol or NA applied at $10 \mu \mathrm{M}$ (data not shown).

\section{Absence of effect of orexin on VPL and lateral geniculate neurons}

Finally, we studied the actions of orexins in the somatosensory and visual relay nuclei of the thalamus. In contrast to the situation 
in the CM neurons and the Rh neurons, no neurons in the VPL and DLG were affected by orexins A or B (applied at 50-100 nM; $n=0$ of 6 in the VPL and 0 of 6 in the DLG), as illustrated for the VPL (Fig. 3A,C,E). Although unaffected by the orexins, both VPL and DLG neurons were depolarized and excited $(n=2$ of 2 in both nuclei) by carbachol and NA applied at $10 \mu \mathrm{M}$ (data not shown).

\section{DISCUSSION}

The present study demonstrates that neurons of the CM intralaminar and $\mathrm{Rh}$ midline nuclei are strongly depolarized and excited by the orexins through postsynaptic $\mathrm{OX}_{2}$ receptors. In contrast, neurons of the VPL somatic and DLG visual sensory relay nuclei, which like the $\mathrm{CM}$ and $\mathrm{Rh}$ nuclei are sensitive to NA and $\mathrm{ACh}$, are completely insensitive to the orexin peptides. The results suggest that orexin can promote waking via the thalamus by acting on the nonspecific thalamocortical projection system to stimulate cortical activation.

In both the $\mathrm{CM}$ and $\mathrm{Rh}$ nuclei, the orexins depolarized and excited all of the cells examined. The depolarizing action of the orexins in these nuclei is similar to the depolarizing actions of orexins documented on other neurons of the arousal systems (see below). In both the $\mathrm{CM}$ and the $\mathrm{Rh}$ nuclei, it appears that the excitatory action is mediated by $\mathrm{OX}_{2}$ receptors, given the greater potency in these nuclei of orexin $\mathrm{B}$. The excitatory action of orexin is also mediated by $\mathrm{OX}_{2}$ receptors on cholinergic neurons of the basal forebrain (Eggermann et al., 2001) and histaminergic neurons of the tuberomammillary nucleus (Bayer et al., 2001; Eriksson et al., 2001). On noradrenergic locus ceruleus neurons (Bourgin et al., 2000), the excitatory action of orexin appears instead to be mediated by $\mathrm{OX}_{1}$ receptors. These electrophysiological data are consistent with in situ data showing prominent $\mathrm{OX}_{2}$ and minimal $\mathrm{OX}_{1}$ receptor expression by neurons in the intralaminar and midline nuclei (Marcus et al., 2001).

The depolarizing action of orexin on thalamic neurons, which was always accompanied by an increase in membrane resistance, should result from the closure of a potassium conductance, because neurons held at $E_{\mathrm{K}}$ never responded to orexin. It is noteworthy that a similar mechanism has been demonstrated previously for the effect of orexin on neurons of the locus ceruleus (Ivanov and Aston-Jones, 2000). Interestingly, however, in contrast to these results, the depolarizing action of orexin on neurons of the tuberomammillary (Eriksson et al., 2001) and laterodorsal tegmentum (Burlet et al., 2002) nuclei was accompanied by an increase in membrane conductance. In the tuberomammillary nuclei, in which the underlying mechanism was sought, the effect of orexin was shown to result from the activation of both a sodium-calcium exchanger and a calcium current.

In striking contrast to the CM and Rh neurons, VPL and DLG neurons were completely insensitive to the orexins, both A and $\mathrm{B}$. These electrophysiological data are consistent with an apparent lack of expression of either $\mathrm{OX}_{1}$ or $\mathrm{OX}_{2}$ receptors (Marcus et al., 2001) and the lack of innervation by orexinergic fibers in these nuclei (Peyron et al., 1998). The lack of effect of the orexins on sensory relay neurons was contrasted by the confirmed, well known excitatory action of NA and ACh on such cells (McCormick and Bal, 1997).

The present results indicate that orexin does not act on the sensory relay nuclei of the specific thalamocortical projection system but rather on intralaminar and midline nuclei of the nonspecific thalamocortical projection system, which are densely innervated by orexinergic fibers. Without directly modifying sen- sory transmission through the thalamus, orexin would stimulate widespread cortical activation and thus sensory responsiveness by acting on those nuclei that give rise to widespread cortical projections (Herkenham, 1980; Groenewegen and Berendse, 1994). The origins of these projections include the intralaminar CM nucleus, the anterior cingulate area (known to be particularly important for arousal) (Hofle et al., 1997), and the midline Rh nucleus, virtually all cortical areas (Berendse and Groenewegen, 1991). Via its dense innervation of these intralaminar-midline nuclei and potent postsynaptic effect, orexin can thus promote the widespread cortical activation of wakefulness.

A potent excitatory action of orexin on the nonspecific thalamocortical projection system would complement its role as a key neuromodulator for the promotion and maintenance of the cortical activation that subtends wakefulness (as cited in the introductory remarks). From both in vivo and in vitro studies, it now appears that orexin has an excitatory action on multiple systems that directly or indirectly stimulate cortical activation, including the cholinergic, histaminergic, and noradrenergic neurons, as mentioned above (Hagan et al., 1999; Horvath et al., 1999; Bourgin et al., 2000; Ivanov and Aston-Jones, 2000; Methippara et al., 2000; Bayer et al., 2001; Eggermann et al., 2001; Eriksson et al., 2001; Huang et al., 2001; Xi et al., 2001; Burlet et al., 2002). Whereas the noradrenergic neurons are excited through $\mathrm{OX}_{1}$ receptors, the intralaminar-midline nuclei, like the forebrain cholinergic and histaminergic neurons, are excited through $\mathrm{OX}_{2}$ receptors, which are those deficient in narcoleptic dogs (Lin et al., 1999). It would thus appear that in addition to its $\mathrm{OX}_{2}$-mediated action on cholinergic and histaminergic neurons, the similarly mediated action of orexin on the nonspecific thalamocortical projection system may be particularly important for stimulation and maintenance of the cortical activation subtending wakefulness. The loss of this influence in cases of human or animal narcolepsy could underlie the symptom of excessive daytime sleepiness that is among the prime symptoms of a disease also characterized by nocturnal sleep disturbances and cataplexy (Hungs and Mignot, 2001).

\section{REFERENCES}

Bayer L, Eggermann E, Serafin M, Saint-Mleux B, Machard D, Jones BE, Mühlethaler M (2001) Orexins (hypocretins) directly excite tuberomammillary neurons. Eur J Neurosci 14:1571-1575.

Berendse HW, Groenewegen HJ (1991) Restricted cortical termination fields of the midline and intralaminar thalamic nuclei in the rat. Neuroscience 42:73-102.

Bourgin P, Huitron-Resendiz S, Spier AD, Fabre V, Morte B, Criado JR, Sutcliffe JG, Henriksen SJ, de Lecea L (2000) Hypocretin-1 modulates rapid eye movement sleep through activation of locus ceruleus neurons. J Neurosci 20:7760-7765.

Burlet S, Tyler CJ, Leonard CS (2002) Direct and indirect excitation of laterodorsal tegmental neurons by hypocretin/orexin peptides: implications for wakefulness and narcolepsy. J Neurosci 22:2862-2872.

Chemelli RM, Willie JT, Sinton CM, Elmquist JK, Scammell T, Lee C, Richardson JA, Williams SC, Xiong Y, Kisanuki Y, Fitch TE, Nakazato M, Hammer RE, Saper CB, Yanagisawa M (1999) Narcolepsy in orexin knockout mice: molecular genetics of sleep regulation. Cell 98:437-451.

de Lecea L, Kilduff TS, Peyron C, Gao X, Foye PE, Danielson PE, Fukuhara C, Battenberg EL, Gautvik VT, Bartlett FS, Frankel WN, van den Pol AN, Bloom FE, Gautvik KM, Sutcliffe JG (1998) The hypocretins: hypothalamus-specific peptides with neuroexcitatory activity. Proc Natl Acad Sci USA 95:322-327.

Deschênes M, Paradis M, Roy JP, Steriade M (1984) Electrophysiology of neurons of lateral thalamic nuclei in cat: resting properties and burst discharges. J Neurophysiol 51:1196-1219.

Dodt HU, Zieglgansberger W (1994) Infrared videomicroscopy: a new look at neuronal structure and function. Trends Neurosci 17:453-458

Eggermann E, Serafin M, Bayer L, Machard D, Saint-Mleux B, Jones BE, Mühlethaler M (2001) Orexins/hypocretins excite basal forebrain cholinergic neurones. Neuroscience 108:177-181. 
Eriksson KS, Sergeeva O, Brown RE, Haas HL (2001) Orexin/hypocretin excites the histaminergic neurons of the tuberomammillary nucleus. J Neurosci 21:9273-9279.

Groenewegen HJ, Berendse HW (1994) The specificity of the "nonspecific" midline and intralaminar thalamic nuclei. Trends Neurosci $17: 52-57$

Hagan JJ, Leslie RA, Patel S, Evans ML, Wattam TA, Holmes S, Benham CD, Taylor SG, Routledge C, Hemmati P, Munton RP, Ashmeade TE, Shah AS, Hatcher JP, Hatcher PD, Jones DN, Smith MI, Piper DC, Hunter AJ, Porter RA, Upton N (1999) Orexin A activates locus coeruleus cell firing and increases arousal in the rat. Proc Natl Acad Sci USA 96:10911-10916.

Hara J, Beuckmann CT, Nambu T, Willie JT, Chemelli RM, Sinton CM, Sugiyama F, Yagami K, Goto K, Yanagisawa M, Sakurai T (2001) Genetic ablation of orexin neurons in mice results in narcolepsy, hypophagia, and obesity. Neuron 30:345-354.

Herkenham M (1980) Laminar organization of thalamic projections to the rat neocortex. Science 207:532-535.

Hofle N, Paus T, Reutens D, Fiset P, Gotman J, Evans AC, Jones BE (1997) Regional cerebral blood flow changes as a function of delta and spindle activity during slow wave sleep in humans. J Neurosci 17:4800-4808.

Horvath TL, Peyron C, Diano S, Ivanov A, Aston-Jones G, Kilduff TS, van den Pol AN (1999) Hypocretin (orexin) activation and synaptic innervation of the locus coeruleus noradrenergic system. J Comp Neurol 415:145-159.

Huang ZL, Qu WM, Li WD, Mochizuki T, Eguchi N, Watanabe T, Urade Y, Hayaishi O (2001) Arousal effect of orexin A depends on activation of the histaminergic system. Proc Natl Acad Sci USA 98:9965-9970.

Hungs M, Mignot E (2001) Hypocretin/orexin, sleep, and narcolepsy. BioEssays 23:397-408.

Ivanov A, Aston-Jones G (2000) Hypocretin/orexin depolarizes and decreases potassium conductance in locus coeruleus neurons. NeuroReport 11:1755-1758.

Jahnsen H, Llinás R (1984) Electrophysiological properties of guineapig thalamic neurones: an in vitro study. J Physiol (Lond) 349:205-226.

Jones BE (2000) Basic mechanisms of sleep-wake state. In: Principles and practice of sleep medicine, Ed 3 (Kryger MH, Roth T, Dement WC, eds), pp 134-154. Philadelphia: Saunders.

Kilduff TS, Peyron C (2000) The hypocretin/orexin ligand-receptor system: implications for sleep and sleep disorders. Trends Neurosci 23:359-365.

Lin L, Faraco J, Li R, Kadotani H, Rogers W, Lin X, Qiu X, de Jong PJ, Nishino S, Mignot E (1999) The sleep disorder canine narcolepsy is caused by a mutation in the hypocretin (orexin) receptor 2 gene. Cell 98:365-376.

Lu XY, Bagnol D, Burke S, Akil H, Watson SJ (2000) Differential distribution and regulation of $\mathrm{OX} 1$ and $\mathrm{OX} 2$ orexin/hypocretin receptor messenger RNA in the brain upon fasting. Horm Behav 37:335-344.
Marcus JN, Aschkenasi CJ, Lee CE, Chemelli RM, Saper CB, Yanagisawa M, Elmquist JK (2001) Differential expression of orexin receptors 1 and 2 in the rat brain. J Comp Neurol 435:6-25.

McCormick DA, Bal T (1997) Sleep and arousal: thalamocortical mechanisms. Annu Rev Neurosci 20:185-215.

Methippara MM, Alam MN, Szymusiak R, McGinty D (2000) Effects of lateral preoptic area application of orexin-A on sleep-wakefulness. NeuroReport 11:3423-3426.

Nishino S, Ripley B, Overeem S, Lammers GJ, Mignot E (2000) Hypocretin (orexin) deficiency in human narcolepsy. Lancet 355:39-40.

Paxinos G, Watson C (1997) The rat brain in stereotaxic coordinates, Ed 3. San Diego: Academic.

Peyron C, Tighe DK, van den Pol AN, de Lecea L, Heller HC, Sutcliffe JG, Kilduff TS (1998) Neurons containing hypocretin (orexin) project to multiple neuronal systems. J Neurosci 18:9996-10015.

Peyron C, Faraco J, Rogers W, Ripley B, Overeem S, Charnay Y, Nevsimalova S, Aldrich M, Reynolds D, Albin R, Li R, Hungs M, Pedrazzoli M, Padigaru M, Kucherlapati M, Fan J, Maki R, Lammers GJ, Bouras C, Kucherlapati R, et al. (2000) A mutation in a case of early onset narcolepsy and a generalized absence of hypocretin peptides in human narcoleptic brains. Nat Med 6:991-997.

Sakurai T, Amemiya A, Ishii M, Matsuzaki I, Chemelli RM, Tanaka H, Williams SC, Richardson JA, Kozlowski GP, Wilson S, Arch JR, Buckingham RE, Haynes AC, Carr SA, Annan RS, McNulty DE, Liu WS, Terrett JA, Elshourbagy NA, Bergsma DJ, et al (1998) Orexins and orexin receptors: a family of hypothalamic neuropeptides and $G$ protein-coupled receptors that regulate feeding behavior. Cell 92:573-585

Siegel JM (1999) Narcolepsy: a key role for hypocretins (orexins). Cell 98:409-412.

Steriade M, Llinás RR (1988) The functional states of the thalamus and the associated neuronal interplay. Physiol Rev 68:649-742.

Steriade M, Jones EG, McCormick DA (1997) Thalamus. Oxford: Pergamon.

Sutcliffe JG, de Lecea L (2000) The hypocretins: excitatory neuromodulatory peptides for multiple homeostatic systems, including sleep and feeding. J Neurosci Res 62:161-168.

Thannickal TC, Moore RY, Nienhuis R, Ramanathan L, Gulyani S, Aldrich M, Cornford M, Siegel JM (2000) Reduced number of hypocretin neurons in human narcolepsy. Neuron 27:469-474.

van den Pol AN (1999) Hypothalamic hypocretin (orexin): robust innervation of the spinal cord. J Neurosci 19:3171-3182.

Willie JT, Chemelli RM, Sinton CM, Yanagisawa M (2001) To eat or to sleep? orexin in the regulation of feeding and wakefulness. Annu Rev Neurosci 24:429-458.

Xi M, Morales FR, Chase MH (2001) Effects on sleep and wakefulness of the injection of hypocretin-1 (orexin-A) into the laterodorsal tegmental nucleus of the cat. Brain Res 901:259-264. 